\title{
Allosteric Learning Model in English Lesson: Teachers' Views, the Instructions of Curriculum and Course Book, A Sample of Daily Lesson Plan
}

\author{
Hasan Güner Berkant ${ }^{*}$, Seda Baysal \\ Department of Educational Sciences, Kahramanmaras Sutcu Imam University, Kahramanmaras, Turkey
}

Copyright $(2017$ by authors, all rights reserved. Authors agree that this article remains permanently open access under the terms of the Creative Commons Attribution License 4.0 International License

\begin{abstract}
The changes which occur during the learning process have been explained by many teaching-learning models and theories. One of these models is allosteric learning model (ALM) which was developed by André Giordan in 1989. This model was derived from a biological metaphor related to proteins. The interaction between individual and environment in a learning situation is tried to be clarified by using a metaphor of allosteric regulation. This regulation explains how enzymes and proteins can change form and function according to the environmental factors, in the same way, the model explains how individuals can change their minds as a result of environmental conditions. Various studies have been conducted in science especially in biology about allosteric regulations; however, there are few studies available especially in Turkey in social and educational sciences and foreign language teaching related to ALM. Hence, the main purpose of this study is to determine the compatibility of English teachers' views and instructions of curriculum as well as $5^{\text {th }}$ grade English course book with the principles of ALM. Moreover, the study aims to present a sample of daily lesson plan for the use of ALM in English lessons. The teachers' views and the data from the curriculum show that most of the ALM principles are available in the curriculum, course books, and classroom activities. Only three of them are not integrated into the curriculum and $5^{\text {th }}$ grade English course book. This study also presents theoretical explanations of ALM and a sample of daily lesson plan prepared for the $5^{\text {th }}$ grade English lesson "Health" unit. Accordingly, in-class activities of sample were developed through the principles of ALM. The current study also provides a framework for an experimental study which is planned to be realized in another study in the future.
\end{abstract}

Keywords Allosteric Learning Model, English Lesson, Teachers' Views, Daily Lesson Plan, Curriculum and Course Book

\section{Introduction}

The definition of learning varies among theorists, researchers, and practitioners [1]. Shunk [2] presents a general definition of learning as an everlasting change both in behavior and in different forms of experience as well as practices. The in-depth examination of this definition reveals that learning may not be seen directly; instead it is observed through its consequences or indicators. In particular, people learn when they become competent in performing something in a different way but this is not a simple process. Wirth and Perkins [3] also indicate that learning should not be just an easy way of acquiring knowledge during the teaching process, and new concepts can not be learned permanently. It means that each of the learners has several questions and ideas in their minds that are interpreted and developed by means of various channels [4] and the traditional methods for transmitting theoretical knowledge into practice do not meet the expectations [5].Thus, a critical shift regarding the learning process over several decades has been from a conception of "learner as sponge" toward an image of "learner as active constructor of meaning" [6].

When the learner is accepted as a constructor of meaning and knowledge, the concept of constructivism comes to the forefront. The early models that are mainly based upon constructivism have been severely criticized for having limitations to refer to multiple learning mechanisms. Besides, these models define learning as a complex process in which the internal and external factors become parts of learning activities instead of as a simple process. It is generally considered that deconstruction of the learner's concepts must be the first stage, though hard. The learner may not allow himself/herself to give up his opinions and beliefs so easily, which turn out to be numerous competences. At that point, the characteristics of the ALM which was developed by Giordan in 1989 have been elicited [7]. ALM defines learning as the transformation of conceptions with the changing learning environment. Giordan developed this model as an alternative to complement the shortcomings of 
the constructivist model. There are some estimations related to the idea that those who support constructivism discard an individual learner, not paying adequate attention to environment. It is also claimed that constructivist model minimizes the role of the environmental factors by putting emphasis on the cognitive capacities [8]. However, the ALM according to which learning is not just accumulating process but the production of new meaning through transformations advocates that construction and deconstruction can merely be interactive processes within an appropriate environment [9].

The ALM was derived from a biological metaphor related to proteins. The interaction between individual and environment in a learning situation is revealed through a metaphor of allosteric regulation which explains how enzymes and proteins can change form and function depending on the environmental factors, in the same way, the model explains how individuals can change their minds as a result of environmental conditions [10]. When it comes to the functioning of the ALM, learners are "the authors" of their own learning and they have their own instruments that are regarded as conceptions. It is described as a behavioral and cognitive strategy which is used for organizing the learner's environment. During the learning process of a new concept, the learner's cognitive structure is fundamentally transformed, the frame of questioning is completely reformulated, and reference filter is broadly restructured [8] and the main variables of ALM come to mind. Having developed the model, Giordan [5] implies that there are three basic variables within the model including the learner, didactic environment (didactic or didactic team) and conceptions. The learner acquires the new knowledge with his/her own style and rhythm in order to find the real answers. Didactic environment is the total elements that integrate behavioral and mental structure. The learner acquires knowledge by constantly comparing the potential sources and didactic environment. Conception consists of five variables. Problem (P) is the pool of questions which provides the putting in place of a conception. Frame of reference (C) is the ensemble of conceptions which learners use to produce a new conception. Mental operations $(\mathrm{O})$ are the collection of intellectual operations or transformations that the learner has. They ensure to make inferences and to produce and use the conceptions. Semantic network (R) is the interactive organization developed from the frame of reference and from mental operations. It allows one to give a semantic coherence to the whole. This process produces a network of meanings and gives a specific sense to the conception. Signifiers (S) are the signs, traces, and symbols required for the production and the explanation of the conception.

Thus, conceptions provide learners' questioning (problems), reasoning and interpretation (mental operations), different opinions (frame of reference), ability of self-expression (signifiers) and the way of meaning making (semantic network). All these factors are closely associated with one another $[4,11]$ and related to the idea of knowledge is the rare product of a simple transfer process. Knowledge comes out as a result of the learner's questions [12]. Besides its explanatory value, the ALM refers to five main obstacles to learning which are observed at different levels. First, learners may miss the required knowledge. Second, learners are not motivated to alter their cognitive conceptions. Third, learners are unwilling to ask questions as they assume that they already possess the knowledge. Fourth, learners are unable to get the information for several reasons such as methodology, operations, and referentials. Last but not least, learners have cognitive skills that hinder them from accessing new knowledge [13]. Taking into account these obstacles, the structure of new knowledge may be altered by interpreting it. Unless compliance is achieved, new information will be completely and absolutely denied. The transformation process is presented schematically in Figure $1[9]$.

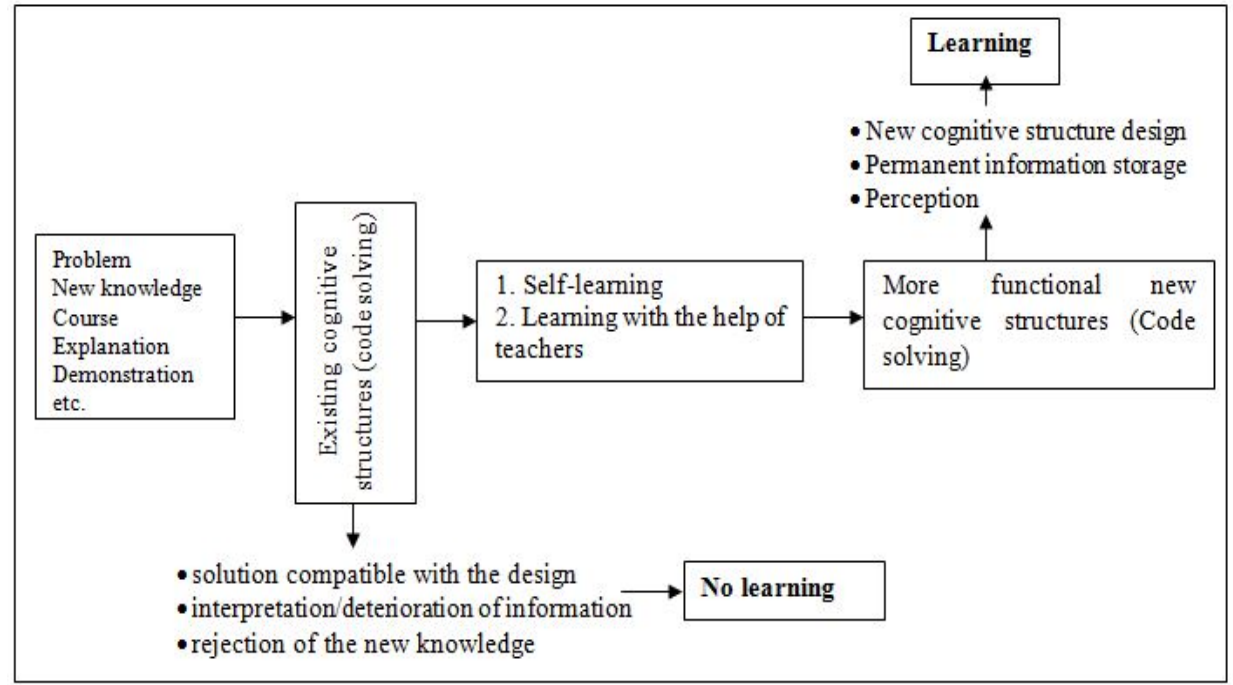

Figure 1. The process of transformations [9] 
As indicated in Figure 1, new information should be in accordance with the objectives of prior knowledge in order to be directly perceived by students. This means that teachers do not directly transfer knowledge to the students; instead they are supposed to take students' cognitive structures into account, to ensure active participation, to impair students' cognitive structure through arising questions and to design learning environment accordingly $[4 ; 7 ; 8 ; 14]$. In this context, the ALM is based upon the following principles:

(1). The adaptation to the changing learning environment: To implement the activities depending upon the changing learning environment

(2). Recalling the prior knowledge: To urge students' prior knowledge and readiness

(3). Destructuring conceptions: To impair the existing knowledge structure of students

(4). Restructuring conceptions: To reform students' cognitive conceptions

(5). Developing a new conceptual framework: To highlight the concepts during the implementation process of the activities

(6). Different levels at which learning is played: To provide learning activities including different levels of cognitive domain

(7). Active participation to the learning environment: To provide students with participating in the activities actively

(8). The transformation of cognitive conceptions: To present various activities for effective learning

(9). The dynamic and systemic aspect of the development of knowledge: To provide activities for students expressing themselves verbally or in writing

(10). The realization of the functionality of the meaning: To ensure students how to use the knowledge in their daily lives

(11). A real confrontation: To present examples from real life for project and performance studies as well as in-class and out-of-class activities

The model helps to provide new insights for learning by rejecting the linearity of the acquisition of knowledge, articulating it around the concept of design, and paying more attention to the educational context. It refines the particular understanding of "what really goes on in the head of the learner" and reveals a certain number of parameters to transform his thinking [9]. These fundamental principles of the model have been integrated into the stages of a lesson plan. Each stage has been redesigned based on of these principles.

Among the studies of related literature, limited numbers of studies have been found about the use of ALM $[1 ; 4 ; 5 ; 7 ; 11$; $12 ; 13 ; 14]$ and its effectiveness on $7^{\text {th }}$ grade English lessons in Turkish education system [15]. Differently from the related literature, this study is based on the $5^{\text {th }}$ grade English lesson "Health" unit and Should/Shouldn't subject, and tries to put forward the principles of ALM clearly. Thus, an English lesson plan has been developed to demonstrate a prepared sample plan in terms of the principles of ALM to teachers and encourage students to participate actively in the learning process. The reason why English lesson has been chosen is that it is considered as one of the main lessons as well as being a must for communicating internationally. Also, ALM may be considered as an alternative way for learning foreign language. Moreover, the sample plan proposed here also presents an opportunity for English lessons to be taught through an alternative method.

\section{Aim of Research}

The main aim of this study is to determine the compatibility of English teachers' views and instructions of curriculum as well as $5^{\text {th }}$ grade English course book with the principles of ALM. Moreover, the study aims to present a sample of daily lesson plan for the use of ALM in English lessons. In this context, the answers to the following questions have been sought:

1. What are English teachers' views towards their use of the principles of ALM in English lessons?

2. Which principles of ALM are included in the curriculum and the $5^{\text {th }}$ grade English course book?

3. How can an English lesson be planned in terms of the principles of ALM?

\section{Methodology}

In this section, the information about the model, sample and material, data collection tools, and data collection and analysis process of the study have been presented.

\subsection{The Model of Study}

This research is based on triangulation design that includes interview and document analysis as two kinds of qualitative research methods. The interviews have been realized for collecting data from teachers about their ideas towards the problematic situation of the study. Document analysis has been carried out for the data which can be derived from the written materials [16]. In this study, the interviews have been conducted with the English teachers and document analysis has been carried out through a unit of the curriculum and course book of an English lesson. Also, in a synthesizing approach, a sample of daily lesson plan based on ALM for the English courses has been proposed in the present study.

\subsection{The Sample and Material of Study}

Having a triangulation design, the study both includes the sample and material. The sample of study consists of eleven English teachers who are working in secondary schools in Turkey during 2016-2017 educational years. Among the English teachers, 6 were women while 5 were men. Also, their ages vary between 45 and 24 years old while their seniorities change between 2 and 24 years. The study used 
convenience sampling technique to contact with teachers easily. The material of study comprises the written documents of "Health" unit which takes place in the curriculum [17] and $5^{\text {th }}$ grade English course book[18] in Turkey.

\subsection{Data Collection Tools}

The interviews with the sample were realized by using semi-structured interview form which was developed through the principles of ALM stated in the introduction part of the present study. The form includes nine open-ended questions about whether the English teachers use the principles of ALM in Health unit or not. Expert opinion was taken during the development of form. Also, another form including the principles of ALM was used for document analysis data.

\subsection{Data Collection and Analysis}

The data of interviews were collected from the sample by the interviews and each of them lasted for 15-20 minutes. The answers of English teachers to the questions of interview form were recorded by means of a voice-recorder. On the other hand, the data of document analysis were collected from the Health unit of the curriculum and course book of secondary school English lessons by the description of the availability of principles of ALM. Descriptive analysis technique was used in data analysis.

\section{Findings}

In this section the findings derived from the interviews and document analysis data are presented.

\subsection{The Findings for English Teachers' Views towards Their Use of the Principles of ALM}

This part includes the findings related to English teachers' views towards their use of the principles of ALM. The teachers who teach $5^{\text {th }}$ graders respond to nine questions each of which is related to the ALM principles. Table 1 presents teachers' views on whether they integrate ALM principles into their teaching process.

As is seen in Table 1, the majority of teachers are of the opinion that they use ALM principles in one point or another in their courses. Upon analyzing the first interview question that is mostly related to the second principle of ALM, all teachers think that they are competent in urging students' preliminary knowledge. Some of the teachers' views that support this finding are as regards: “...First, I am trying to have students remember what they have learned before.
Then, I provide students with understanding the unit with an ease by associating the prior knowledge with this unit." "Yes, I do this. I present a short review of previous topics and ask questions about them for one hour."

When it comes to the second interview question which refers to the principle called "the realization of the functionality of the meaning", approximately half of the teachers stated that they are not able to motivate students sufficiently for the use of knowledge they have acquired in daily life due to several reasons. Accordingly, the teachers express their opinions as following: “... Unfortunately no. Most of the activities that are available within the unit are not directly related to daily life..." "No. I have doubts as to whether English will be used in the conditions of our daily life or not." Whereas, rest of the teachers have positive views regarding the use of knowledge that students have acquired in their daily lives. One of them mentions that "I provide students with adapting what they have learned to their daily lives through asking them preparing performance homework or projects. The task is mostly related to the use of language. For example, I ask them to go to a chemist and want the medicine in English..."

As for the third interview question that has been asked in order to determine whether teachers "develop a new conceptual framework", all of the teachers believe that they always teach the basic concepts related to the unit to students. Some of the teachers' views, in this regard are as follows: "I make it possible for learners to learn the vocabulary items visually and audibly by means of the smart board." Another teacher emphasized that "Repetition is crucial in language learning. I do not tell the Turkish meanings of the words. Instead, I try to motivate students for guessing the meaning of the words through using flashcards, pictures etc. For pronunciation, I make students repeat them personally or in groups during the lesson..."

As shown in Table 1, almost all of the teachers are free from changing and recreating the existing knowledge structure of students during the lesson, which means that the principles "destructuring and restructuring conceptions" have not been met. Some of the teachers' views support this finding: "I mostly prefer to relate the existing knowledge to the new one instead of destructuring and restructuring it, as it is highly difficult for the students at this age to change and recreate their knowledge." Another teacher states that "Students are not endowed with knowledge due to the inappropriate language teaching." However, only one teacher concludes that about destructuring and restricting knowledge "Yes, I ask several questions to students and try to make them realize the missing and incorrect knowledge they have. Then, I ask them to guess the correct answer, if they cannot give any responses to the questions, I explain them through examples." 
Table 1. English teachers' views towards their use of the principles of ALM

\begin{tabular}{|c|c|c|}
\hline The research questions regarding the views of teachers towards their use of the ALM principles & $\begin{array}{l}\text { Yes } \\
(\mathrm{f})\end{array}$ & $\begin{array}{l}\text { No } \\
\text { (f) }\end{array}$ \\
\hline 1. Do you urge the preliminary knowledge of your students during the lesson? (Principle 2) & 11 & 0 \\
\hline $\begin{array}{l}\text { 2. Do you have any effort to motivate students for the use of knowledge they have acquired in daily life during the lesson? (Principle } \\
\text { 10) }\end{array}$ & 5 & 6 \\
\hline 3. Do you highlight basic concepts during the teaching process? (Principle 5) & 11 & 0 \\
\hline 4. Are you trying to change and recreate the existing knowledge structure of students during the lesson? (Principle 3-4) & 1 & 10 \\
\hline 5. Do you perform the activities of the "Health" unit in the changing learning environment? (Principle 1) & 8 & 3 \\
\hline 6. Do you provide the active participation of the students in the activities? (Principle 7) & 11 & 0 \\
\hline 7. Do you use different activities in your courses? (Principle 6-8) & 10 & 1 \\
\hline 8. Do you organize activities that enable students to express their knowledge about the subject verbally/in writing? (Principle 9) & 11 & 0 \\
\hline $\begin{array}{l}\text { 9. Do you include various studies based upon in-class/out-of-classroom, life-oriented project and performances from daily life? } \\
\text { (Principle 11) }\end{array}$ & 9 & 2 \\
\hline
\end{tabular}

Moreover, taking the sixth interview question into account, it is inevitable to witness the fact that all of the teachers provide active participation of the students in the activities. One of them thinks that "Yes, I ensure student-student interaction through in-class and out-of-class activities. I allocate sufficient time for each activity so that all students can participate actively."

The obtained views about the seventh interview question illustrate that the two of the principles called "different levels at which learning is played and the transformation of cognitive conceptions" have been mostly welcomed by teachers. Some of the statements of teachers on this point have been presented as such: "I provide students various reading passages and listening activities for both the related illnesses and different ones." On the other, only one teacher has a negative view on the use of different activities as "No, the materials and activities are enough. There is no need for extra activities."

Furthermore, all teachers' responses to the eighth interview question about the organization of activities that enable students to express their knowledge about the subject verbally / in writing has been determined to be positive. Hence, one of the teachers stressed that "Yes, I use role-play activities to motivate students for speaking and I ask students to write dialogues." While another teacher indicated "Students write the questions on their paper and then ask them each other at the end of the activity." This shows that the principle "the dynamic and systematic aspect of the development of knowledge" is mostly included in the activities.

As for the last interview question that is related to the availability of various activities based upon in-class and out-of-class, life-oriented project, and performances from daily life, most of the teachers have positive views as regards: "So that students understand the topic in depth, I ask them to prepare projects about the real life events." "Students prepared flashcards with regard to the unit. They integrate them into their daily lives through making practice at home, at school etc." Compared to these views, only two teachers mention that "No, the book does not include activities that are performed out-of-class, so students cannot prepare performance homework or projects."

\subsection{The Findings for the Availability of ALM Principles in Curriculum and English Lesson Course Book}

This part holds the findings related to the availability of the principles of ALM in the $5^{\text {th }}$ grade curriculum and English lesson course book. The principles of ALM have been determined whether they are available in the curriculum, and several samples from the curriculum have been presented.

The findings for the availability of ALM principles in the English lesson curriculum are presented in Table 2.

As indicated in Table 2, the curriculum holds most of the principles of ALM and corresponding activities are determined as student-centered in the context of active learning approach. Considering acquisitions like expressing basic needs, expressing feelings, making simple suggestions, talking about possessions and telling someone what to do are mostly related to the principle which is called "the realization of the functionality of the meaning". When it comes to the skills such as listening, speaking, and reading, it may be wise to emphasize that they mostly refer to "active participation to the learning environment, developing a new conceptual framework, the realization of the functionality of the meaning, the transformation of cognitive conceptions and the dynamic and systematic aspect of the development of knowledge." As the curriculum does not include the writing skill, it is unlikely to determine whether it includes ALM principles or not. Therefore, the writing skill may be integrated into the curriculum so as to provide "a real confrontation" which is one of the ALM principles. As for the suggested lexis, the vocabulary items are mostly related to the principle "developing a new conceptual framework", and most of the activity types that are presented in the curriculum as drama/miming, games, speaking, real-life tasks imply "a real confrontation, the realization of the functionality of the meaning, the adaptation to the changing learning environment". In the assessment section, projects such as preparing a picture story and role play having an illness is mostly related to the principles "a real 
confrontation, active participation to the learning environment, and the transformation of cognitive conceptions". However, Table 2 also depicts three principles which are not integrated into the curriculum. These are; recalling the prior knowledge, destructuring conceptions and restructuring conceptions.

The findings for the availability of ALM principles in the English course book are presented in Table 3.

Table 3 depicts the availability of ALM principles in the $5^{\text {th }}$ grade English course book. Upon analyzing the course book, eighth of the ALM principles are highlighted in the activities. For instance, the activity which is called listening the conversation, ordering the sentences about an illness and acting out is related to the principle "the adaptation to the changing environment". The activities about reading the sentences regarding illnesses and giving advice mostly refer to the principle "developing a new conceptual framework". Further, "active participation of the students to the learning environment" is the mostly observed principle within the course book. One of the activities, in this regard, is listening to the dialogue and sticking the names of the illnesses to the paper. Another practice that is mainly based upon the principle called "the dynamic and systematic aspect of the development of knowledge" is about singing a song that tells about an illness. However, the three principles of ALM "destructuring conceptions, restructuring conceptions and the recall of the prior knowledge" are not available within the "Health" unit of the English course book. The same deficiency is determined in the English lesson curriculum as mentioned in Table 2.

Table 2.The availability of the ALM principles in the curriculum

\begin{tabular}{|c|c|c|}
\hline The principles of ALM & The availability & Samples from the divisions and activities of curriculum \\
\hline $\begin{array}{l}\text { 1.The adaptation to the changing learning } \\
\text { environment }\end{array}$ & Available & $\begin{array}{l}\text { Suggested text: Songs, stories, cartoons conversations, fables are used } \\
\text { during the teaching process. }\end{array}$ \\
\hline 2.Recalling the prior knowledge & Not available & - \\
\hline 3.Destructuring conceptions & Not available & - \\
\hline 4.Restructuring conceptions & Not available & - \\
\hline 5.Developing a new conceptual framework & Available & $\begin{array}{l}\text { Suggested lexis: The vocabulary items such as "back, cough, names of } \\
\text { illnesses etc." are presented. }\end{array}$ \\
\hline 6.Different levels at which learning is played: & Available & $\begin{array}{l}\text { Reading: Students will be able to comprehend short, simple texts about } \\
\text { illnesses and people's needs and feelings especially when they are } \\
\text { accompanied by pictures. }\end{array}$ \\
\hline $\begin{array}{l}\text { 7.Active participation to the learning } \\
\text { environment }\end{array}$ & Available & $\begin{array}{l}\text { Activity types: Drama, miming, games etc. are the activities that are } \\
\text { planned to be used in class. }\end{array}$ \\
\hline 8.The transformation of cognitive conceptions & Available & $\begin{array}{l}\text { Assessment: Students role play having an illness and their friends tell } \\
\text { them what they should do to get better. }\end{array}$ \\
\hline $\begin{array}{l}\text { 9. The dynamic and systemic aspect of the } \\
\text { development of knowledge }\end{array}$ & Available & $\begin{array}{l}\text { Assessment: Students prepare a picture story and tell what they need } \\
\text { when they are sick. }\end{array}$ \\
\hline $\begin{array}{l}\text { 10.The realization of the functionality of the } \\
\text { meaning }\end{array}$ & Available & $\begin{array}{l}\text { Communicative functions \& skills: Expressing feelings, telling someone } \\
\text { what to do. }\end{array}$ \\
\hline 11.A real confrontation & Available & $\begin{array}{l}\text { Activity types: Students are provided real-life tasks, speaking, } \\
\text { story-telling etc. }\end{array}$ \\
\hline
\end{tabular}

Table 3.The availability of the ALM principles in the English course book

\begin{tabular}{|c|c|c|}
\hline The principles of ALM & The availability & Samples from the activities of course book \\
\hline $\begin{array}{l}\text { 1.The adaptation to the changing learning } \\
\text { environment }\end{array}$ & Available & $\begin{array}{l}\text { Listening the conversation, ordering the sentences about an illness and } \\
\text { acting out }\end{array}$ \\
\hline 2.Recalling the prior knowledge & Not available & - \\
\hline 3.Destructuring conceptions & Not available & - \\
\hline 4.Restructuring conceptions & Not available & - \\
\hline 5.Developing a new conceptual framework & Available & Reading the sentences regarding illnesses and giving advice \\
\hline 6.Different levels at which learning is played & Available & $\begin{array}{l}\text { Students are engaged in different activities, such as listening, ordering, } \\
\text { matching, singing, asking, etc., providing them learning in different } \\
\text { levels of learning domains. }\end{array}$ \\
\hline $\begin{array}{l}\text { 7.Active participation to the learning } \\
\text { environment }\end{array}$ & Available & $\begin{array}{l}\text { Listening to the dialogue and sticking the names of the illnesses to the } \\
\text { paper }\end{array}$ \\
\hline 8.The transformation of cognitive conceptions & Available & Matching the pictures with words. \\
\hline $\begin{array}{l}\text { 9. The dynamic and systemic aspect of the } \\
\text { development of knowledge }\end{array}$ & Available & Singing a song that tells about an illness \\
\hline $\begin{array}{l}\text { 10.The realization of the functionality of the } \\
\text { meaning }\end{array}$ & Available & $\begin{array}{l}\text { Ask your friends such questions as "How do you feel now? Are you } \\
\text { OK?" }\end{array}$ \\
\hline 11.A real confrontation & Available & Looking at the pictures and talk about what Jenny should do. \\
\hline
\end{tabular}




\section{Results, Discussion and Recommendations}

The fact that the student 'participates actively' in the development of his/her knowledge has been for long years. However, when it comes to the active process of learning, studies concerning the conceptions of the learners go much further. In this regard, new models have been produced to explain teaching and learning process, for instance ALM [4; $5 ; 7 ; 8 ; 10]$. By the same token, ALM which notably shows certain characteristics of constructivism is a try to go beyond constructivist philosophy. This model opens new gates for the functioning of thoughts as well as putting great emphasis on the adaptation to the changing learning environment. It is also observed that ALM activities are learner-centered and students ensure active participation to the learning environment. Active participation requires the use of some characteristics of students. Among them, cognitive structure is one of the most important factors. Students are ready to go to school with cognitive structures such as reasoning, perception, and comprehension. During the teaching-learning process, these structures should be taken into account and interaction-based activities should be developed.

One of the behaviors which require the use of cognitive structure and interactions with social environment is learning language. When it is taken into consideration that the use of language requires the ability of adaptation to the changing environments, ALM may be used as an alternative way for teaching language [15]. Because language learning is a process by which students delve into different worlds with different cultures. Thus, language is best learned through personally meaningful contexts with the need for an appropriate methods and techniques in a changing didactic environment. English language learners may also be quite more successful when they ensure the relation of the new conceptual framework with the prior knowledge at different levels and in different conditions. This differentiation may help educators integrate student-centered activities in their courses that evoke a sense of wonder in students. Besides, they should be cognizant of motivating students, raising questions in students' minds, and reorganize the didactic environment to narrow the gaps.

This research has examined the compatibility of English teachers' lessons and instructions of curriculum and course book of secondary school English lesson with the principles of ALM. Moreover, the study aims to present a sample of daily lesson plan for the use of ALM in English lessons. English teachers' views towards their use of the principles of ALM during the teaching process have been analyzed. Accordingly, "the recall of the prior knowledge, developing a new conceptual framework, active participation to the learning environment and the dynamic and systemic aspect of the development of knowledge" has been determined as the mostly used ALM principles for all teachers. Other principles used in a descending order are different levels at which learning is played, the transformation of cognitive conceptions, a real confrontation, the adaptation to the changing environment, the realization of the functionality of meaning, destructuring conceptions, and restructuring conceptions. The principle that teachers cannot integrate into their lessons is destructuring and restructuring conceptions. Gürbüztürk, Koç and Babaoğlu [15] conclude that ALM activities are learner-centered and students can choose the activities depending on their level and further they can "participate actively". Topbaş [19] reports that meaningful learning takes place as a result of the learners' personal activities in order to ensure the acquisitions of new conceptions in a real sense. Moussu and Roux [20] indicate that solving problem, cooperation, enhancing socio-cognitive dynamics, and teacher's managing scientific debates play significant role during the learning process. These findings don't show parallelism with the present study in that teachers don't motivate sufficiently students for the use of knowledge they have acquired in daily life. However, almost all teachers stated that they cannot change and recreate the existing knowledge structure of students during the lesson. Instead, they mostly prefer to relate the existing knowledge to the new one instead of destructuring and restructuring it. This may result from the time constraint and the necessity to catch up with the curriculum. Giordan (2006b) reports that students must motivated and encountered with an imbalance and stimuli for arising question in their minds.

In this research, the availability of ALM principles in curriculum and English lesson course book has also been analyzed. The principles of ALM have been determined whether they are available in the curriculum, and several samples from the curriculum have been presented. It has been found that the curriculum holds most of the principles of ALM. Thus, the reading, listening, and speaking skills provide "active participation to the learning environment, developing a new conceptual framework, the realization of the functionality of the meaning, the transformation of cognitive conceptions and the dynamic and systematic aspect of the development of knowledge". As the curriculum does not include any activities toward writing skill, it is unlikely to determine whether it includes ALM principles or not. Therefore, the writing skill may be integrated into the curriculum so as to provide "a real confrontation" which is one of the ALM principles. Moreover, the analyses depict the non-availability of three principles that consist of the "recall of the prior knowledge, destructuring conceptions, and restructuring conceptions". This finding is parallel to the views of teachers who participated in the study. Even though the curriculum does not include any activities for the recall of the prior knowledge, teachers have several attempts to prepare extra materials in this regard. Besides, $5^{\text {th }}$ grade English course book has been investigated in terms of the availability of the ALM principles. Eight of the ALM principles have been determined to be available in the activities. As in the curriculum, the activities in the course book do not include the three principles of ALM such as "the recall of the prior knowledge, destructuring conceptions, and 
restructuring conceptions".

In present study, it is accepted that the ALM can be realized by using its principles in class activities. On this point, the sample lesson plan is prepared depending upon these principles that have been indicated in theoretical explanations of introduction section. Before the sample, the stages of a lesson plan with regard to the principles of ALM have been presented. The aim is to assure the harmonization of the principles with the sample plan. This harmonization may be accepted as an optional selection; in that, this selection can be changed with different perspectives. It may be accepted as an important guideline that a sample plan should be compatible with the principles of ALM. As indicated in current study, each stage of the sample plan holds one or more principle as the principles are not sorted according to the stages.

Given the limitations of present study, the sample lesson plan has been prepared only for English lesson, the class period is limited to three course hours, and merely one unit that is called "Health" has been chosen with a view to preparing an ALM based lesson plan. In this regard, new daily lesson plans may be developed for other units or in other courses such as social sciences, science, maths etc. by using the principles of ALM. Class period may be prolonged to ensure more effective teaching and learning environment. The current study also provides a theoretical framework for an experimental study which is planned to be realized in another study in future. It may be wise to implement and test the lesson plans in classes in future studies.

The general characteristics which present the specific activities of each stage of lesson plan and a sample plan that may be used by English teachers as a guide for organizing their lessons in terms of the principles of ALM are given below:

The application of ALM principles in lesson planning: To apply the basic principles of the Allosteric lesson a number of steps should be taken: In the warm up stage, learners will confront with the problem and try to compare the information available with the new one. Cognitive dissonance will occur and a sense of wonder will evoke. In motivation stage, learners' motivation will be ensured providing the realization of the functionality of the meaning knowledge in daily life situations. In the goal clarification stage, students are let know about the acquisitions which they will get at the end of the lesson. When it comes to the review stage, the main titles and concepts of the subject or topic of lesson are demonstrated to students to draw a framework in their cognitive schemas. In the transition to practice stage, students are realized about the start of main activities of lesson. As to the practice, learners thus face with a problem which makes the driving force of mental activity. The teacher who serves as the information designer guides learners to participate in the learning process. At this stage, students are ensured to encounter with the sources. It also provides for students to form their cognitive structures through establishing relationships with references. Learners achieve whole ness by comparing information and data. The learning environment is changed and differentiated, and students are promoted and expected to be adapted to the new conditions. Prediction is provided through achieving results and relationship among students is ensured. Student-student and student-environment interactions are enhanced. Students create networks and significant indicators by self-expression. Learners are provided to reach new cognitive structure by generating knowledge. In the general revision stage, linearity is exceeded by repeating previous things in order to enable learning. Full summary is done with students by questions and answers. Results are found. Then, learners' re-motivation is ensured providing the realization of the functionality of the meaning of knowledge in daily life situations. In the measuring and evaluation stage, students are measured and evaluated about what they have learned. They are informed about their mistakes through feedbacks provided by the teacher. Lastly, in the practice stage, practicing the knowledge they have learned is ensured by preparing performance works and the out-door activities based on investigation and researching.

Sample of Daily Lesson Plan with regard to the Principles of Allosteric Learning Model: In this subsection, a sample of daily lesson related to English lesson based on the principles of ALM. The acquisitions have been obtained from the 5th grade English lesson curriculum [15] that was developed by the Ministry of National Education in Turkey. The numbers of the principles of ALM which are mentioned in introduction are integrated into the sample plan by using abbreviation such as $\mathrm{P} 1, \mathrm{P} 2$, etc.

Lesson: English

Grade: $5^{\text {th }}$

Theme: Health

Linguistic form: Should/Shouldn't

Class Period: 40+40+40 minutes

Acquisitions: Expressing feelings, making simple suggestions, telling someone what to do.

Teaching-Learning Methods and Techniques: Question-answer, small group discussion, argumentation, self-study, brain storming, story completion.

Instruments: Flashcards, projector, images, video, and observation form.

\section{A. Introduction to Lesson}

Warm up: Students are told they will watch a video about a man who has several illnesses and a girl who gives bad advice (P3). After that, students are asked several questions related to the video (P7). For instance, "What kind of advice does the girl give? "Did you feel anything strange about this advice?" Students are listened but correct answers are not provided for them.

Motivation: Teacher says "At the end of the lesson, you will learn when people around you are ill and how to describe your feelings when you are ill" (P10).

Goal clarification: Students are told that they will learn health problems and advices (P5).

Review: At this stage, teacher mentions that our body is 
our most valuable treasure and we need to behave consciously to protect this treasure. Who would like to remind for protecting our body? (P2-P7). Toothache, backache, headache, fever, runny nose, stomachache, and cough." (P5).

Transition to practice: The models of Snow White and seven dwarves who are ill which are prepared in advance are presented to students. The teachers glue them to the walls of the class.

\section{B. Practice}

The first activity starts with the teacher's miming health problems one by one and students are told to guess what the problem is through brain storming technique and the answers are written on the board (P7). After the brain storming, the teacher glues the names of health problems on the board and wants students to match the names with the ill dwarves and write the answers (P4-P5-P7). Then the papers are collected and handed out to the class randomly. The teacher wants the students to read them aloud. During the lesson, students' concept errors are paid attention. Instead of being explained by the teacher, students are expected to realize their errors. Students are expected to underline the errors and write the correct answer. At the end of the activity, the papers are given back to the children to provide them for seeing their errors. Then, the papers are added to the product file (P5-P6-P7-P8).

Each of the students is asked to prepare one flashcard which includes the picture of an ill dwarf. The teacher prepares the pictures before and the students glue them on the apple shaped cartons. However, they are asked not to tell one another which dwarf and health problem they select. Then, each student comes to the board and tries to tell the problem to the class by using miming or verbal statement without saying the name of the illness. The rest of the class tries to guess the illness (P1-P5-P7-P8).

Then, students are divided into groups according to the type of illness. Each group is given a worksheet that includes a story about an ill boy and they are expected to complete it. At the end of the activity, each group tells the story to the class with the help of a leader selected by group members (P6-P8-P9-P10).

\section{Ending the lesson}

General revision: Students are asked questions about the video they had watched at the beginning of the lesson. They are asked what they have learned and the answers are written on the board. The answers are discussed and some advice is given to the ill man in the video (P7-P9-P10-P11).

Re-motivation: The teacher says "You have learned what to advise when people around you are ill and how to describe your feelings when you are ill” (P5-P9-P10).

Homework: Students are asked to observe and make an interview with an ill person. During preparing homework, they are expected to interview the indicators of the illness and give suggestions to the ill person and get down their observations. Their homework is measured through a rubric (P7-P8-P9-P10-P11).
Measuring and evaluation: Students' learning outcomes during the learning process are evaluated through semi-structured observation form including rating scale as well as measuring to use the concepts, express feelings, make simple suggestions, tell someone what to do etc. The feedbacks are given to show the learning outcomes (P9-P10).

\section{REFERENCES}

[1] M. Moradi, S. Brunel, B. Vallespir. Design a product for learning and teaching: From theories to developing a process, Online available from https://hal.archives-ouvertes.fr/hal-003 23144 .

[2] D. H. Schunk. Learning Theories. An Educational Perspective, Pearson, Boston, 2012.

[3] K. R. Wirth, D. Perkins. Learning to learn, Online available from http://www.macalester.edu/geology.

[4] A. Giordan. Les conceptions de l'apprenant: un tremplin pour l'apprentissage, Sciences Humaines, Vol.12, 48-50, 1996b.

[5] A. Giordan. New models for the learning process: Beyond constructivism? in Prospects, Vol.25, No.1, 101-118, 1995.

[6] S. M. Wilson, P. L. Peterson. Theories of Learning and Teaching What Do They Mean for Educators? National Education Association, N.W. Washington, 2006.

[7] A. Giordan, Le modèle allostériqueet les theories contemporaines sur l'apprentissage, Online available from http://www.ldes.unige.ch

[8] A. Giordan, Comment Transformer Une Conception Progressivement, Online available from http://www.ldes.unig e.ch/publi/vulg/enseignerPasApprendre.pdf.

[9] G. Gojkov. Didactic limitations of constructivistic learning model in teaching, Metodickiobzori, Vol.6, No.3, 19-40, 2011 .

[10] A. Giordan, The allosteric learning model and current theories about learning. (Trans. Nadine Allal), Online available from http://cms.unige.ch/ldes/wpcontent/uploads/2012/07/The-allo steric-learning-model-and-current-theories-aboutlearning1.pd f.

[11] E. Topbaş. Öğrenmeyi anlamada yeni bir model: Allosterik öğrenme, Eğitim Bilimleri Kongresi, Gaziosmanpaşa Üniversitesi, 140-147, 2007.

[12] E. Topbaş. Allosterik Öğrenme Modelive Sınıfiçi Uygulaması, Pegem Akademi, 2013.

[13] F. Pellaud, R. E. Eastes, A. Giordan. Un modèle pour comprendre l'apprendre: le modèle allostérique, Gymnasium Helveticum, Vol.1, 28-34, 2005.

[14] F. Pellaud, R.E. Eastes, A. Giordan. Des modèles pour comprendre l'apprendre: de l'empirisme au modèle allostérique, Gymnasium Helveticum, Vol.5, 10-14, 2004.

[15] O. Gürbüztürk, S. Koç, H. M. Babaoğlu. The effect of allosteric learning model on the problem solving skills of 7 th grade students in English courses, Journal of Education and 
Future, 67-82, 2016.

[16] K. F. Punch. Introduction to social research. London, UK: Sage Publications, 2005.

[17] MEB, İlköğretim Kurumları (İlkokullarve Ortaokullar) İngilizce Dersi (2, 3, 4, 5, 6, 7 ve 8. sınıflar) Öğretim Programı, Ankara, 2013.

[18] MEB, Secondary School $5^{\text {th }}$ Grade Student's Book, Online available from http://www.eba.gov.tr/ekitapdetay/2216.
[19] E. Topbaş. Gazi University Education Faculty of Commerce and Tourism Office Management Education Second Grade Students' Views Towards Five Stage Learning Strategy, $7^{\text {th }}$ National Office Management and Secretariat Congress, 22-24 October.

[20] M. J. Moussu, J.P. Roux. De l'émergence des conceptions chez des élèves de cycle 3 à l'acquisition de saviors scientifiques relatifs au volcanisme: une approche socio-constructiviste. Communication au colloque " L'enseignement de la terre de l'école à l'université », Nice, France, 2003. 